\title{
北海道に於ける輸出球根類の栽培に關する研究 III
}

鐵砲百合花粉の撥第並に花粉管の俳長に就いて

\author{
明道博 \\ (北海道大學辳學部)
}

H. MYodo : The cultivation of bulbs for exports in Hokkaido III.

On the pollen tube development and growth

of the Easter lily (Lilium longiflorum)

\section{緒言}

從來本邦に於汀る鐵盷百合栽培に㐫つてはての媻殖か： 殆えど全く木子並に鱗片による無性繁殖によつてい，實 生法洔特殊の場合を除き行方机ていなからた。一方北米 合衂國にあつては同々から種子に上る實生繁殖法が廣く 探用され(6)，最近では相當大昷の生黄を擧げている如く である。勿論此の葢生法にも若干の缺整あるにしろ多く の利點も考兄られるもので夜つて，從來世界の特產地之 して海外に廣々乞の市場を有している本邦としては是非 共訊多らるべきである。

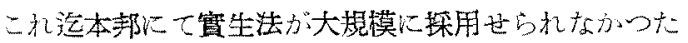
理由は多乃あるであるうがての主たるるのと考えられる

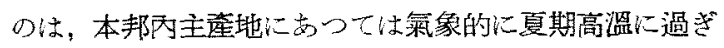
る䉆稚苗狀態で一夏越さ权ばなら鐵砲百合にあっては 此の眝期に枯損率の硕る高いものが岕る。併乍ら他方本 邦有にあつて此の障害が少いであるうと考昔られる北海 道に於ける此の種試㯺方從來行わ机なかつたのは事惯で

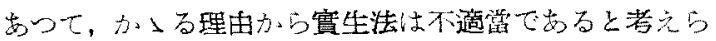
れて來た。

箠者は昭和 22 年以來鐵㿣百合の䆩生繁殖法に關して 筫驗做究を進めているるのであるが，筫生法は何といの ても形筫の不齊一であるといらことがての缺點であつ て，此の形質固定に對して更に鐵㿣百合が頗る高い目家 不稳性な示すということが大きな障害となつている。

鐵䣱百合の自家不稳性は併乍与完全てはなく，若干 の朱に自家可稳のものが見ら机る。この゙こは先に BRIERLEY等(1によつて報告せられ，筆者も實際に確め ている。文育種作業として授粉に際し一般に袋㨴子を行 うか此の場合隔離して open で自家授粉过しものに比し て結翼䇣が頗る少るといらことが報告されている。更に 最近侄つて EMSWELLER等(2)は Naphthalene acetamide $の$ lanolin paste 老花桂の基部に粱布して自家可 稔率を高的たと言う。
以上の事項を以て見るに鐵歾百合の自家授精延いては 品留の固定には或る程度の存空が持てるものでる。か

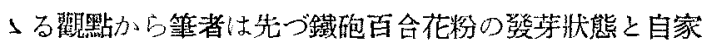
授泾 (self pollination) 並に他家授粉 (cross pollina-

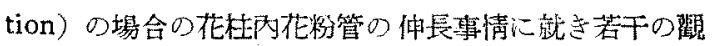

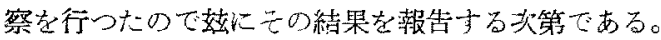

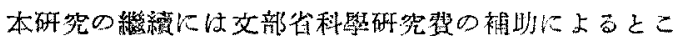
るが多い，趃に梁く感謝する次箢でする。

\section{1. 實驗材料及び方法}

實驗に供した鐵殉百合花粉は北大㖘學部花少園に栽培 せる極早生青軸鐵砲百合及び黑触鐵砲百合の惯生株に着 生せる花上り探つた斥のであるか滩 7 月 8 日實驗のもの

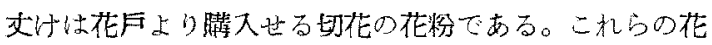
粉は探取後直りに使用せるものの他は $3^{\circ} \sim 5^{\circ} \mathrm{C}$ 冷藏㢍肉 に於てグリ七リンを弱乾燥齌とせるデジーター中にて 25 日以內の貯藏にからるものである。

㑑用女る寒天は市販の寒天老 5〜8時閒流水により洗

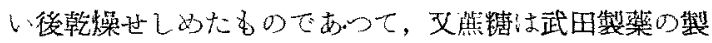
品安用いた。上記塞天の $2 \%$, 䓵煻 $4 \%$ を以て再蒸溜

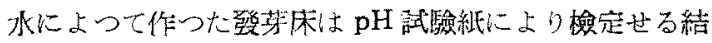
果はその $\mathrm{pH}$ は 5.8〜6.0であつた。

花䓉の播付けは塞天床及び桂頭に對しては成熟莉から

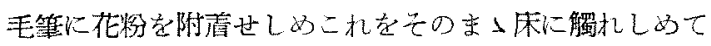

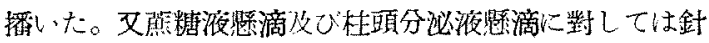

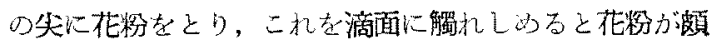
るよく滴面に均等に摭まるのてこの力法によつた。

$20^{\circ} \mathrm{C}$ 以上の發芽溫度には地下空の恒溫槽を用いたが 此の場合士 $1^{\circ} \mathrm{C}$ 以上の差はなかった。 $17^{\circ} \mathrm{C}$ という溫度 は地下室空溫を利用したが $\pm 3{ }^{\circ} \mathrm{C}$ 以內の差があつた。 更に $11^{\circ} \mathrm{C}$ は水道水流水に上つて得た溫度だすつて $\pm 2^{\circ} \mathrm{C}$ 以內の差に止つた。

花粉管の染色は純乳酸溶媒とせる0.05\%のG。 Grübler \& Co. 裴 cotton blue 在使用した。 


\section{2. 不完全花粉並に不發芽花粉の混在率}

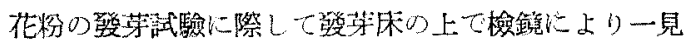
L. て發芽不可能な花粉郎方形態的に不稔の花粉が若干混 在する上共に形態的には完全ですつて吸水膨满し得ても 發芽し得ない花枌がある。前者は普通內容志缺くか或は 內容を有していても形加さく双不整形てあってこれる 確めることは容易てある。一力後者はどういういか充

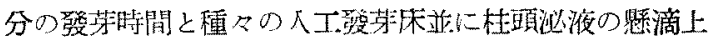
に於ても發芽し得ないものであつて便笪上こ札を不品芽 花粉とし，これらの觀察總花粉數に對与る比率を出した ものが第1表である。本表に示された數字の中第1包調

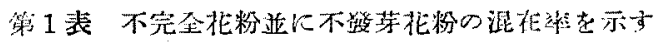

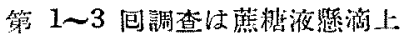
第 4 国調查は柱頭议液上

\begin{tabular}{|c|c|c|c|c|c|c|}
\hline \multirow{2}{*}{ 調 查别 } & \multirow{2}{*}{$\begin{array}{l}\text { 調查 } \\
\text { 糸數 }\end{array}$} & \multirow{2}{*}{ 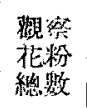 } & \multicolumn{2}{|c|}{ 不完全托粉 } & \multicolumn{2}{|c|}{ 不政芽批粉 } \\
\hline & & & 筫數 & $\%$ & 貨數 & $\%$ \\
\hline 第 1 & 9 & 845 & 60 & 7.1 & 370 & 44.7 \\
\hline 第 2 国調查 & 3 & 84 & 5 & 5.9 & 51 & 60.7 \\
\hline 第 3 回調查 & 4 & 80 & 8 & 10.0 & 49 & 61.2 \\
\hline 訫 & 16 & 1009 & 73 & - & 470 & - \\
\hline 平 & 5.3 & 336.3 & 24.3 & 7.6 & 156.6 & 55.2 \\
\hline 第 4 包調查 & 2 & 102 & 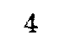 & 3.8 & 18 & 17.4 \\
\hline
\end{tabular}

查は 10 月 2 日（實生䢹開花初年度は 7 月下旬上り降

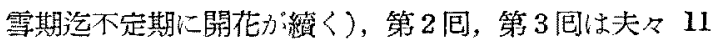

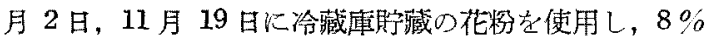

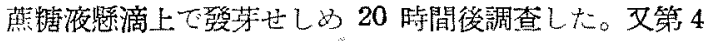

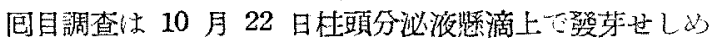
5 時間後調查せるものであつて何扎も $28^{\circ} \sim 30^{\circ} \mathrm{C}$ 恒溫槽 內た行つたものである。上表の結果から見机壮形態的不 完全花粉の湿在率は 4 10\% と見做寸ことが出來る。一 方生理的不墢芽花枌の％は人工贸芽床の場合々杜頭泌 湤上に於ける場合とて大分差があり，前者の埸合時間的 には20時間という古分な時間發芽㕅に置いたのであ るが夰 40〜60\%の高率を示している心對し，後者で $17.4 \%$ であつた。蓋し人工筑芽床としては完全なもの は得難いのであるが，杜顽必液上の不登芽粒％は略碓 實な價に近いのてはないかと考炎る。

\section{3. 溫度との關保}

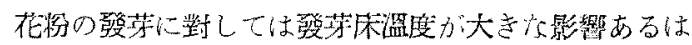
諭を俟たないところであつて多くの植物につきての遥溫

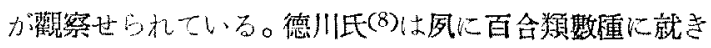

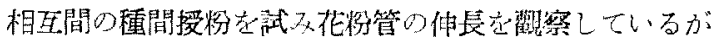

その中で溫度の影蝆に就き雫皮し，L.elegans $\times L$. elegansでは $63^{\circ} \mathrm{F}$ (原著に活㩔氏となりいるむ華民の 俱植と思う)の場合 $80^{\circ} \mathrm{F}$ の場合の略 $59 \%$ の花粉管伸 長度でらったと報じている。

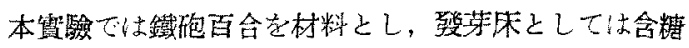
寒天板及び花杜內の 2 種を撰び夫々几就き花粉管の伸長 を調查した。份寒天床としては $2 \%$ 寒天，4\%蕉糖の力 形の本板に切り取つた暗学作りVAN TIEGHEM's cell 中にてこ机に花㸮を播きつけた。花粉管伸長の測定值は 1 視野にあらわれた花粉 70〜120糧につき本均值を以て あらわしたものである。及花杜內の伸長展は授粉後切花 となして恒渭槽內に水㨉し所定時閒後花杜を切り取つて 一度 acetic alcohol 中で固定し，水洗後花杜壁を縱に 裂開して前記 cotton blue て染色後檢鏡し，最も長く伸 骎せるものの杜到加らの長さを以て測定值とした。尖7 月 8 日の第 1 實驗に於ける材料は花戸より切花として瞒 入せるものであつた。第 $2 ， 3 ， 4 ， 5$ 表はこ机旗驗の 結果を示」ものである。

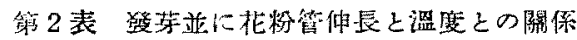
(第 1 四筫聽) 8 時開後

\begin{tabular}{|c|c|c|c|c|c|c|}
\hline 度 & $35^{\circ} \mathrm{C}$ & $30^{\circ} \mathrm{C}$ & $25^{\circ} \mathrm{C}$ & $21^{\circ} \mathrm{C}$ & $17^{\circ} \mathrm{C}$ & $11^{\circ} \mathrm{C}$ \\
\hline 發芽率 \% & $3.0 *$ & 8.5 & 5 & 0 & 0.5 & 0.0 \\
\hline 花粉管長 $\mathrm{mm}$ & 0.2 & 0.9 & 0.4 & 0.3 & 0.1 & 0.0 \\
\hline
\end{tabular}

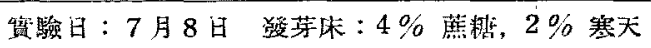

材 料: 花尼上り贆入切托

* 破裂粒多い

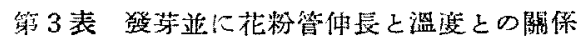
(第 2 问急驗) 9 時阊後

\begin{tabular}{|c|c|c|c|c|}
\hline 溫 & $37^{\circ} \mathrm{C}$ & $35^{\circ} \mathrm{C}$ & $30^{\circ} \mathrm{C}$ & $25^{\circ} \mathrm{C}$ \\
\hline 發芽染 \% & 0.0 & 3.0 & 70.0 & 46.5 \\
\hline 花粉管长 $\mathrm{mm}$ & 0.0 & 0.1 & 3.0 & 1.6 \\
\hline
\end{tabular}

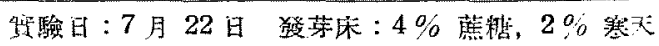
朴 料：青軸寞生

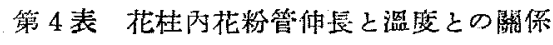
- (第 1 回䔈驗) 24 時閏後

\begin{tabular}{c|c|c|c|c}
\hline 溫 度 & $40^{\circ} \mathrm{C}$ & $35^{\circ} \mathrm{C}$ & $30^{\circ} \mathrm{C}$ & $25^{\circ} \mathrm{C}$ \\
\hline 花粉䈍長 $\mathrm{mm}$ & 3.2 & 45.3 & 45.5 & 22.0 \\
\hline
\end{tabular}

嗐羷日:7月 23 日

材 料: 苦軸賢生 cross pollination

第 2,3 表の結果加ら士ると何札の場合に於ても $30^{\circ} \mathrm{C}$ に最適溫度があることが見られ（第1圖照）、これよ

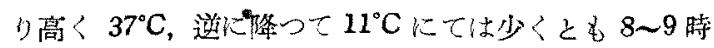




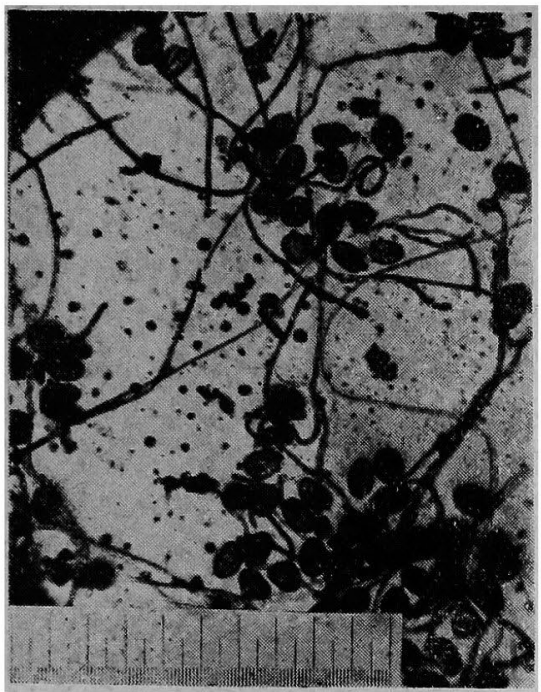

第 1 圆 $30^{\circ} \mathrm{C}$ に於ける花粉管伸長を示す 9 時间闿

登芽床 : $4 \%$ 寒天, $2 \%$ 蔍糖 附尺は $0.01 \mathrm{~mm}$

間後に於二花粉管の伸長せるものは見られなかつた。 $11^{\circ} \mathrm{C}$ の低溫に播かれた花粉は乞の後これを適溫に移し た場合に!正常に發芽を開始するのが見られたが， $37^{\circ} \mathrm{C}$ の溫度に播うれたるのは花粉が破裂して內容を外部に䧉 出せるものが多くこれを後適溫に移した場合少數のもの が發芽し花粉管を伸長せしめたに過ぎなからた。此の花 粉の破裂は $35^{\circ} \mathrm{C}$ の場合でも可成多數見られた(第 2 圖)。

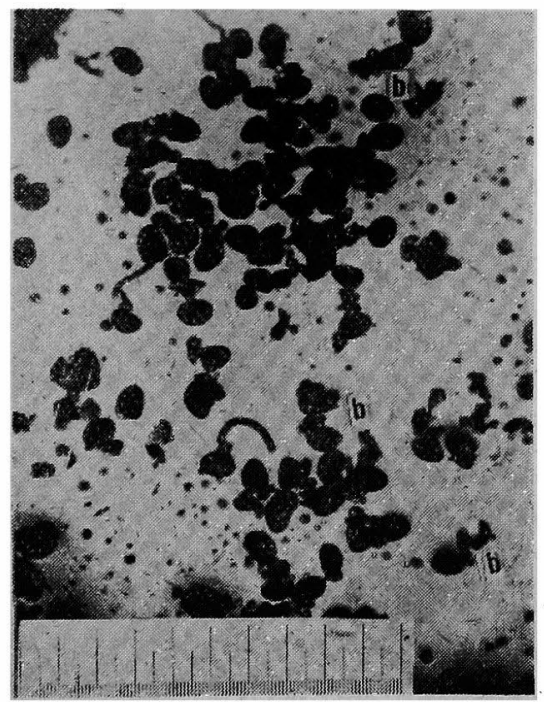

籍 2 阔 $37^{\circ} \mathrm{C}$ に於ける花粉の破裂 (b) 爿況を示す 9 時阔後 發芽床 : $4 \%$ 寒天， $2 \%$ 蕉糖 附尺は $0.01, \mathrm{~mm}$
次に杜頭に授粉せしめたもの】花杜內に於ける花粉管 の伸長度に就いて見るに，第 4 表の結果から $30^{\circ} \mathrm{C}$ に適 溫があると認められる。しかし此の場合 $35^{\circ} \mathrm{C}$ にあつて も可成良好な伸長を示していることが見られ， $40^{\circ} \mathrm{C} に$ 至つて急激に減少するし此の溫度では花粉管の伸長は殆 んど不可能であると考えられる。以上の諾點を確める雼 更に同樣の實驗を繰返した (第 5 表)。郎ち $40^{\circ} \mathrm{C} に 22$ 時間通して曝したものと, $40^{\circ} \mathrm{C}$ に初めの 6 時間邛び 3 時間打き後 $35^{\circ} \mathrm{C}$ に移し計 22 時閒生長せしぬたもの， 呚び $35^{\circ} \mathrm{C} に 22$ 時間おいたものとの 4 通りを設けた。 此の實驗の結果からすると $40^{\circ} \mathrm{C}$ 改び $35^{\circ} \mathrm{C}$ に通して置 いたものは前包實驗と同㨾の結果を示している, 初めの 3 時間文び 6 時間を $40^{\circ} \mathrm{C}$ に曝したものにあつては夫々 $40^{\circ} \mathrm{C}$ の時には殆んど完全に發芽を停止している, 且 $40^{\circ} \mathrm{C}$ に 6 時間あつたものでは後 $35^{\circ} \mathrm{C}$ に移つてからあ 頗る少數の花粉管が伸長したのを見たに過ぎないから此 の時間に死隇也る花粉が多數あつたことを示するのと考 こてよいるのと思う。

第 5 表 花柱內枇粉管伸長と溫度との關係 （第 2 包䫅驗）

\begin{tabular}{c|c|c|c|c}
\hline 溫度並時間 & $\begin{array}{l}40^{\circ} \mathrm{C} \\
22 \text { 時間 }\end{array}$ & $\begin{array}{c}40^{\circ} \mathrm{C} \text { 6時間 } \\
35^{\circ} \mathrm{C} 160^{\circ} \mathrm{C} \text { 時間 }\end{array}$ & $35^{\circ} \mathrm{C} 19$ 時間 & $35^{\circ} \mathrm{C}$ \\
\hline 花粉管長 $\mathrm{mm}$ & 2.9 & $28.0^{*}$ & 38.5 & 45.0 \\
\hline
\end{tabular}

筫驗日：7 月 29 日

材 料: 青軸實生 cross pollination

* 花粉管數極少

\section{4. 發芽床菣糖液賑度己 花粉管伸長との關係}

百合類にはその雌晸が成熟した場合杜頭に夥しく多量 の分泌液を出す鐵砲百合や高砂百合等の如きものと，反 對に極く少量より見られない鹿の子百合や透百合等の如 きものがあつて，これらは花粉墢芽に對して發芽床の組 成に關するものとして興味を學ゆるものである。從來百 合類の花粉發芽床の菣糖濃度に關して MOLISCH(5)は L.Martagon にあっては 1 〜0\% の廣い範圍に於て 發芽し得ることを報じている。又德川氏(8) は百合類數種 の組合せの中で鐵砲百合 $\times$ 透百合並に此の逆の組合を以 て授粉を行い 120 時間以队前者では略花杜の長さの $2 / 8$, 後者では同じく略 $1 / 2$ 迄は花㸮管の伸長が見られた ことが表示されている。以上の報告に上れば百合類花粉 の發芽に對する發芽床の組成特に蕉糖濃度にはさして大 きな影響がない如くである。筆者か鐵砲百合花粉を用い て見たところでは塞天上，菣糖照滴上，水で濡した罳紙 
上, 及び程に裂閶せる花杜壁上等に於て何れるよく發芽 するのが見られた。併しその發芽に對して最適の濃度が 考兄られることは當然であつて此の點からVAN TIEGHEM's cell 中で憼糖液悲滴を以てその optimumを知 らんとして實驗を試みた。その結果を以下記述する（第 $6 ， 7$ 表參照)。被檢の筧糖液濃度は $2 \%, 4 \%, 6 \%$,

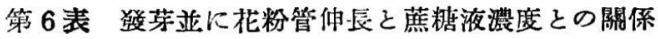
（第 1 可筫驗） 5 時闬後

\begin{tabular}{l|c|c|c|c|c}
\hline \hline 濃 度 & $32 \%$ & $16 \%$ & $8 \%$ & $4 \%$ & $2 \%$ \\
\hline 發芽率 \% & 0.0 & 13.4 & 46.3 & 65.4 & 37.0 \\
花粉管長 $\mathrm{mm}$ & 0.0 & 0.37 & 1.09 & 1.00 & 0.44 \\
\hline
\end{tabular}

筫驗日：11月 2 日 溫度： $28^{\circ} \mathrm{C}$ 材料：黑軸惯生

第 7 表 登芽並に花粉管伸長々蔗糖液㴚度との關保 （第 2 可實驗） 20 時间後

\begin{tabular}{|c|c|c|c|c|c|}
\hline 濃 & $16 \%$ & $12 \%$ & $8 \%$ & $6 \%$ & $4 \%$ \\
\hline 登 芽 率 \% & 41.4 & 41.6 & 58.9 & 56.8 & 31.6 \\
\hline 批粉管長 mm & 2.8 & 1.6 & 4.6 & 3.0 & 2.8 \\
\hline
\end{tabular}

貿驗日：11月 9 日 溫度： $28^{\circ} \mathrm{C}$ 材料：黑軸筫生 $8 \%, 12 \%, 16 \%, 32 \%$ であつてこれらに就き $28^{\circ} \mathrm{C}$ の場合の花粉發芽 \%, 花粉管の伸長度を調查した。表 示された結果の數値は何れも檢鏡の際 1 視野にあらわれ た 19 37 の花粉粒に就き測定計算されたものである。 第 6 表の結果を見るに 5 時間後の没芽率は $4 \%$ 蔴糖液 に於て最も高く $65.4 \%$ を示し， $8 \%$ これに次き 46.3 $\%$ であるが，花粉管の長さは $8 \%$ 藍糖液に於て最大に して $1.09 \mathrm{~mm}, 4 \%$ これに次いで $1.00 \mathrm{~mm}$ となつて いる。而して $2 \% ， 16 \%$ に於ても何上く發芽している が， $32 \%$ 蔗糖液で 5 時間後に至つても未だ發芽せる ものがなからた。この結果から寸机ば從つて 4 ～8％の 䕃度に最適の範图があるものと考光られる。次いで此の 結果を確める鹘に實驗を繰返した第7 表に就いて見てみ

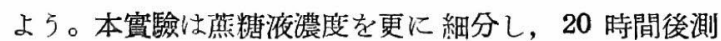
定せるものである。これによると, 發芽率, 花粉管伸長 共 $8 \%$ 葵糖液に於て!最も良好であつて $6 \%$ これに次 いでいる。少 5 時閒後調查の前司實驗に比して $16 \%$ に 於ても本實驗では可成良い發第率を示していることが注 目され，且 $4 \%$ に於て相當劣つているのは花粉管が伸 長してからその尖端に於て破裂するものが若干あつたこ とによるものであろう。以上の實驗結果からすれば，花 粉播付计後少くとも 20 時間以內にあつては, 發芽率, 花粉管伸長の點に於て䈚糖液 4 8\% が最適濃度である と考兄られるものであり，より高い濃度にあつて子時間 の經過に伴つて漸次發芽率の高まることも考兄られる。

\section{5. 自家並飞他家授粉に於け る花柱內花粉管の伸長}

鐵砲百合が自家不和合を示すことは慨に多くの報告が ある。(1),(2),(4) 併しこれが完全不和合でないことも報ぜ られているところであり(1),(3)筆者も24 年夏嘪生株 25

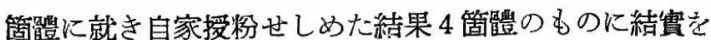
兒た (第 3 圖及び第 8 表)。而して表中 No. 24 と No. 8 とは前年も自家授精が行われて結實し，他の不稔怢々雨 年共不稔であつたから，自家可稔株は系統的にその形質 を具有するものであると考光られる。併乍ら此の場合の 允實粒數は少く，異系統間授㸮の場合の 196 粒 (192 箇 の湖につき本均値）に對し 42.7 粒であつて略 $21 \%$ 沉 過ぎない。

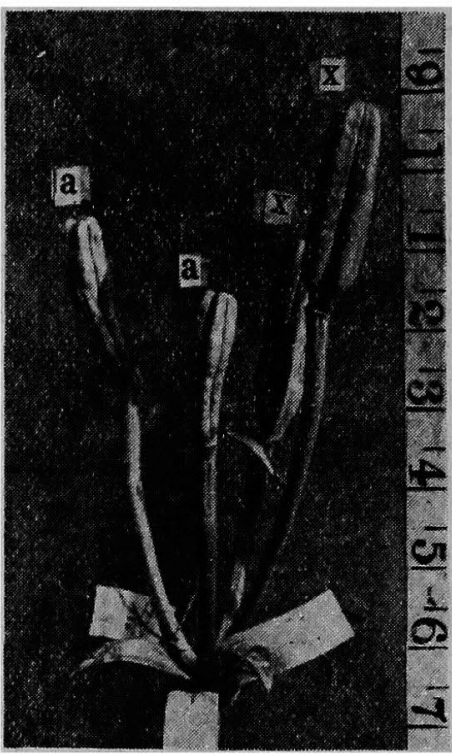

第 3 圖 結實せる朔を示す

a : self pollinated $\mathrm{x}:$ cross pollinated 附尺は寸

節 8 表 自家並に他家授粉に於ける1站中充實種子數

\begin{tabular}{|c|c|c|c|c|c|c|}
\hline 授 粉 別 & \multicolumn{2}{|c|}{ 自 } & 家 & \multicolumn{2}{|c|}{ 粉 } & 他家授粉 \\
\hline 侦生番號 & No. 24 & No. 8 & No. 8 & No. 28 & 平均 & \\
\hline 卷萁種子数 & 89 & 17 & 23 & 42 & 42.7 & 196 \\
\hline
\end{tabular}

* 192 湖平均值

これらの事情から自家授㸮の場合花粉管が如何にして 授精するに至る前に障害を受けるかということは興味あ る問題である。德川氏は鐵砲百合に就き自家授粉と他家 授粉の場合の花恃內花粉管伸長を調查している(8) 仩此つ 
場合 24 時閻後に於て約 $10 \%$ 前者の方が伸長を減じて いな結果となつている。筆者は溫度並に時間を異にする 3回の實驗を繰返して見大結果略 $40 \%$ の減少が見られ た。第 9，10，11 表はその結果である。第 9 㤗の實㓡 では材料は花户より切花として購大せるものを使用し た。第 10，11 表の實驗には共に花斗園围場の新鮮なる 材料を使用しこ机を切花として $30^{\circ} \mathrm{C}$ の恒溫槽中心水插 して受粉したものである。以上の結果から見ると何れの

第 9 表 自家授粉並に他家授粉に於ける花粉管伸長 （第 1 回蒉驗） 23 時間後

\begin{tabular}{c|c|c}
\hline \hline 授粉別 & 自家授粉 & 他家授粉 \\
\hline 花粉管長 mm & 7.0 & 12.0 \\
同上比数 & 58.0 & 100.0 \\
\hline
\end{tabular}

偊驗日：7月 8 日 溫度: $21^{\circ} \mathrm{C}$

材 料：花戶より購入の切花

第10表 自家授粉並に他家授粉に於行る花粉管仲長 (第 2 国賽驗) 42 時间後

\begin{tabular}{c|c|c}
\hline 授粉別 & 自家授粉 & 他家授粉 \\
\hline 花粉管長 ${ }^{*}$ mm & 44.3 & 72.3 \\
同 上 比較 & 61.2 & 100.0 \\
\hline
\end{tabular}

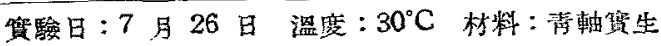

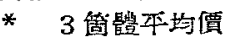

第11表 自家授粉並に他家授粉に於りる花粉管伸辰 （第 3 回實龭） 24 時問後

\begin{tabular}{c|c|c}
\hline 授粉別 & 自家授粉 & 他家授 \\
\hline 花粉管長 $\mathrm{mm}$ & 30.0 & 48.0 \\
同上比數 & 62.5 & 100.0 \\
\hline
\end{tabular}

穓驗日：7 月 27 日 溫度： $30^{\circ} \mathrm{C}$ 材料：毒軸算生

第12表 自家授粉並儿他家授粉に於りる花粉管伸礐

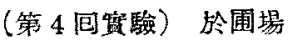

授 粉 時 $^{*}$ 調查日時 $\frac{\text { 花粉管長 } \mathrm{mm}}{\text { 自授粉[他家授粉 }}$

\begin{tabular}{l|l|l|l|l|}
\hline 8 月 3 日11.A.M. & 8 月 8 日10.A.M. & 79.0 & $86.0+a$
\end{tabular}

材料：黑軸鐵砲百合

* 夏期跱刻

第13表 杜頭汹液上に於ける花粉管伸長 5 時間後

\begin{tabular}{|c|c|c|}
\hline 杜瑣泌液別 & 同 & 買 \\
\hline $\begin{array}{l}\text { 薀 芽 } \% \\
\text { 花粉管長 } \mathrm{mm}\end{array}$ & $\begin{array}{l}78.7 \\
1.70\end{array}$ & $\begin{array}{l}78.6 \\
1.63\end{array}$ \\
\hline
\end{tabular}

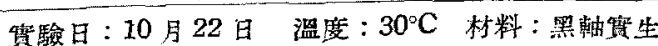

場合も，自家授粉にあっては他家授粉の場合の略 $60 \%$ の伸長に停っていることが制る。

头に第 12 表に擧げた数值は固場に於て授枌 119 時間 後調查せるるのであつて、これによると self pollination で杜頭加 50 距離 $79 \mathrm{~mm}$ 附近迄達している花枌管 が極く少數見られた。併し多數の花㸮管が $35 \mathrm{~mm}$ 附近 にあつたに對し， cross pollination の方は $86 \mathrm{~mm}$ の 花桂を晸過して多繁子房上端に達しているのが胃られ た。

投て前記 42〜23 時間後に於ける觀察では自家授枌に 跉ける花粉管伸長は他家授粉の約 $60 \%$ で西つたが，第 13 表に揭げたものは柱頭泌液を以てこの惯驗を試みた 結果である。材料となつた花は實驗日の1日前に開花正 るものであるが他家授粉の場合の花は若干時間若かつ た。これは 5 時間啳の數値であるがこれによると兩者の 間に㱠ど盖異を見出せなからった。

\section{6. 總括並に考察}

鐵砲百合の成熟花粉は㯬全なものが多數点めてい。 形態的不完全花粉心混在等は $10 \%$ 以下儿停门，生理的 に發芽能力学缺、と思孙るすのを加劣ても20\%以下 であると考光ら机る。球根植栽の場合であると北海道に 於ける鐵䣱百合心開花期は早生系統て 7 月中旬，晚生を 7 月下旬になるか，花粉母細胞の第 1 ，第 2 分裂はこれ 上り約 25〜30 日先行した 6 月中，下旬几行斿る(未

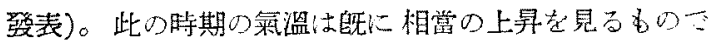
あるが，本報告富驗の㭡生株では開花初年度てあったか ら開花期は不定的二降雪迄續いた篇材料の探取が 11 月 に入つたものもあつたが此の場合 10 月初旬の相當低溫

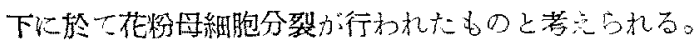
しかしかつる材料にあつても成熟䒺中の不完全花粉量は 大差なく，從つて正常な分裂を經過したものと考只られ る。

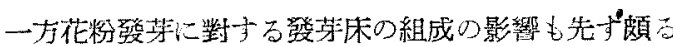
少い部類であつて，杜頭上は勿論寒天床，蕉糖液惩滴， 花柱壁烈開面等何れにてもよく發芽せしめることが出來

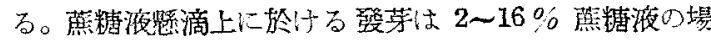
合では $28^{\circ} \mathrm{C} て ゙ 5$ 時間以內儿發芽が見られ，上り長時 間後には $32 \%$ の高䇱度にても發芽可能である(24 時 間後少數の墢芽が見られた。）而してての最適の濃度は 4〜8\%にある様てある。唯此處て注目さ机ることは杜

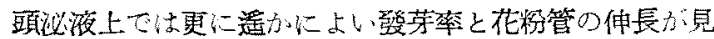
られ，特江開花初日の若、桂頭の必液上り開花後 1 日經 つたものの方がい栐大古る。

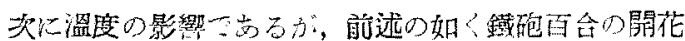


期は北游道では真夏になるから，授粉は最も诺い時期に 於て行われることになる。双下發玡林上に於ける花㹦發 芽兒るに $17^{\circ} \mathrm{C} \sim 35^{\circ} \mathrm{C}$ 海は略順調の樣であるが, $35^{\circ} \mathrm{C}$ 以上ては花粉の破裂死隇与るものが次第に多く $40^{\circ} \mathrm{C}$ て は殆んど不可能の如々でる。此りことは花桂內花粉管

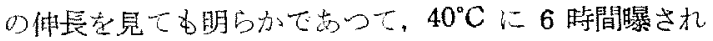
九場合に注殆んど生き殘るものがたく，3时間の場合て

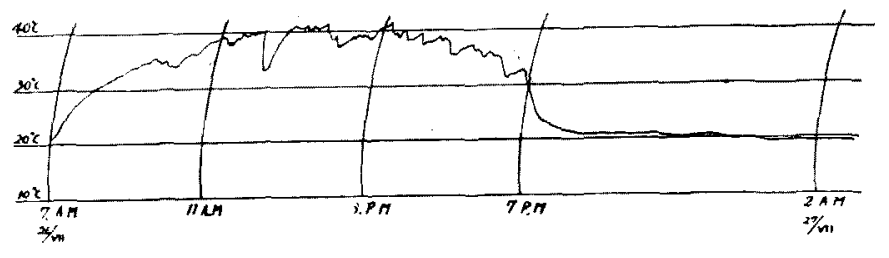

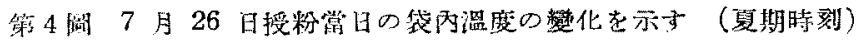

も相虽程度の破裂がある。普涌育種作業として交配に際 し紙势をかけることが行加れるが此の場合結果步合の甚 だ劣るいのが岀ることは㞗經驗するところであつて從來

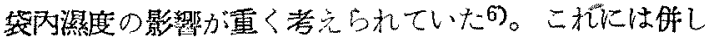
以上の結果から見机袋內溫度の上年によって受ける障

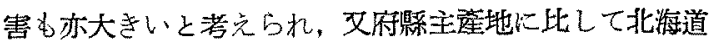
に於ける鐵豞百合の結算には良好なるのがあるがこれに も同じ理由が一部分關與しているであるう 之考光られる。實際等者が炤和 24 年 7 月 26 日にトレーシングベーバーによつて作 つた交配用篦の中に於ける溫度を測定して 見たが(第 4 凧网)これによると午後の0时

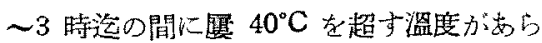
われる。惯際に開题となるのは柱頭並に花

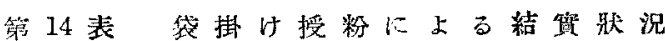

\begin{tabular}{|c|c|c|c|c|c|c|c|c|c|c|c|c|c|c|c|c|c|c|c|c|}
\hline \multicolumn{2}{|c|}{ 授 } & 粉 & 持 * & \multicolumn{2}{|c|}{$7 \mathrm{~A}$. } & \multicolumn{2}{|c|}{$M$} & \multicolumn{2}{|c|}{$11 \mathrm{~A}$. } & \multicolumn{2}{|c|}{$M$} & \multicolumn{4}{|c|}{3 P. M. } & \multicolumn{5}{|c|}{7 P. M. } \\
\hline 倜 & 觜嶄 & 番 & 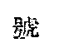 & 1 & 2 & 3 & 4 & 1 & 2 & 3 & 4 & 1 & 2 & 3 & 4 & 1 & 2 & 3 & 4 & 5 \\
\hline 充 & 筫 & 粒 & 数 & 83 & 75 & 52 & 失敢 & 55 & 31 & 9 & 166 & 64 & 10 & 31 & 145 & 82 & 56 & 34 & 42 & 60 \\
\hline 平 & & & 均 & \multicolumn{4}{|c|}{70.0} & \multicolumn{4}{|c|}{65.2} & \multicolumn{4}{|c|}{62.5} & \multicolumn{5}{|c|}{44.8} \\
\hline
\end{tabular}

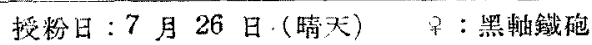

* 夏期時䘞

杜阿の溫度て支るが，若干流これるり低いとしても大瑟 ないことは豫想せら机るとこらでるつて相當の障害を受 けている事資は同日4四に亘つて行つた交配結果に龍、 て見ても分っ (第 14 荠)。郎方第 14 表は黑軸鐵砲百合 を母本として前日除雄して袋掛行を施し7月26日午前 7 時, 午前 11 時, 千後 3 時, 千後 7 時 (夏期時刻)

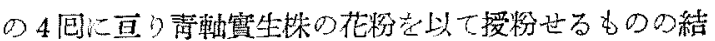
實狀況でり，結筫步合は $93 \%$ を示しているが1朔篦 bの充惯粒數は 44.8 70.0 粘平均 60.6 粒に過ぎい。 こ礼 openの授粉による1新先筫粒數 196 ケ（第 11 表）飞比な九ばての格 $30 \%$ に停つている。更に本表か

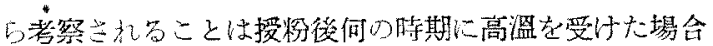
に㜔害が最む大であるかということは餘り制然としな い。少?と花物管伸長中に岁つては何の時期にても高 溫の害は同等化認められるということが言兑ると思う。

次に自家不和合性であるが，これは完全不和合ではな ?，自家授粉心際にむ花枌管束は $35 \mathrm{~mm}$ 位迄伸びている のが認心られ，それ以後伸長が停るがしかしての中若干 のものホ份伸長を結け授棈に至るものがある。又 EMSWELLER 等(2) の報ずる如、生長物賀の添加によつて自 家可稳率高高め5るならば安留氏(9)心主張する肧珠か

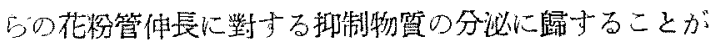

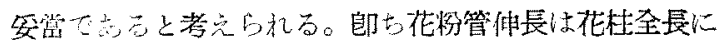

亘つて同樣に抑制せられるといらわけではなく，杜頭綆 液上ては殆えど自家，他家の兩者に於て差が見られない。 これが花杜內罊に入つてから次第に伸長速度が少り，杜 亚加の距離にして $35 \mathrm{~mm}$ 邊加らは前者性略完全に伸 長克抑制される。

\section{7. 摘 要}

1. 鐵酌百合花粉の發第並に花粉管伸長と發芽休溫

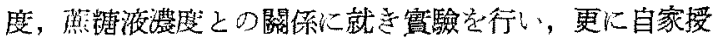

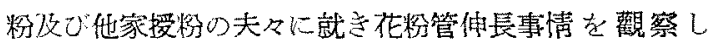
た。

2. 花粉發第の適溫は $30^{\circ} \mathrm{C}$ 附近に見亡，叔， $11^{\circ} \mathrm{C}$ に 於ては少くとも8 時間後迄性臂芽が見られないが一力 $40^{\circ} \mathrm{C}$ の高溫に於ては花粉の破裂するものが頗る多くな るし，弡芽しても花粉管の伸帚は不可能である。

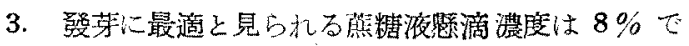
あつたが，2１6\%でも份相堂程度の發芽率を示し， $32 \%$ で 24 時間後少數の發芽せるものを兒た。

4. 自家授枌の場合他家授粉同樣杜頭上の弡芽は良好 に行执れるものと考光られるが，花粉管が花杜內に入っ て 30 40 mm 附近湥は乞の伸長度は略 $1 / 2$ に減し更に それ以後の伸長は目家授猖の場合極少數のものを䟻き偟 此してし亡5。 


\section{8. 參考交獻}

1) Brierley, P., S. L. EMSWeller and J. C. MilLER. (1936) : Easter lily breeding : Compatibilities in Lilium longiflorum stocks. Proc. Amer. Soc. Hort. Sci., 34 : 603-606.

*2) Emsweller, S. L. and Nile W. Stuart. (1948) Use of growthsubstances to overcome incompatibilities in Lilium. Proc. Amer. Soc. Hort. Sci., $51: 581-589$.

3) GRIFfiths, D. (1921): The production of the easter lily in the northern climates. U.S. Dept. Agr. Bull. No. 962.

*4) JoST, L. (1907) : Ueber die Selbststerilităt einiger Blüten. Bot. Zeit., 65 : 73-117.

*5) Molisch, H. (1893) : Zur Physiologie des
Pollens mit besonderer Rücksicht auf die chemotropische Bewegungen der Pollenschlăuche. Sitzungsber. Wien Akad. Wiss. Mattnaturw. Kl., $102: 402-448$.

6) Oliver, G. W. (1903) : The propagation of the Easter lily from seed. U. S. Dept. Agr. Bur. Pl. Ind. Bull. No. 39.

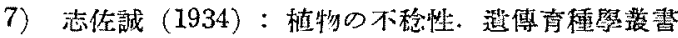
第 4 輯. 猓京.

8) TokUgawa, Y. (1914): Zur Physiologie des Pollens. Jour. Coll. Sci. Tokyo, 35 : 1-35.

9) YaSUDA, S. (1932): On the special substance that inhibits self-fertilization. Bot. Mag. Tokyo, $56: 225-231$.

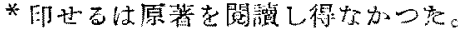

\section{On the Pullem Tube Developmemt and Growth of the Easter Lily (Lilium longiflorum) Hiroshi MYodo}

\section{Summary}

1. Influences of temperature and sugar concentration of the germinating bed upon the pollen tube development and growth of the easter lily were investigated.

2. The optimum temperature for the pollen tube development is recognised to be about $30^{\circ} \mathrm{C}$ and when lowered to $11^{\circ} \mathrm{C}$ they cannot develop their tubes, in $40^{\circ} \mathrm{C}$ on the other hand, most of them will burst in a few hours and if some others may germinate their tube growths are almost impossible.

3. The optimum sugar concentration for the pollen tube development is ascertained to be about
$8 \%$ and though they can germinate freely in a wide range of $2-16 \%$ their germinating percentages and tube growths gradually decrease.

4. Pollen tube developments on the stigma are considered to be much the same in both cases of self pollination and cross pollination, but in the former the rapidity of the pollen tube growth in the stylar cavity is a half of the latter for the first $24-40$ hours after pollination and when they have travelled down about one half to two thirds of the whole length of the style, most of tubes are arrested decidedly.

\section{碑究抄報}

\section{蔴糖は荣面撒布尿素の藥害を防止する}

尿素の葉面施肥の效果法各種の作物て睢認されてい。 る。トマトでは尿素らボンド疌 100 ガロン（0.1 モル

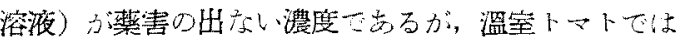
冬季間短日で光線方弱いから炭水化物の生成少く，二 の濃度ても䒚害を生ずる。EMMERT 氏等は尿素溶淮 に尿素々同一モルの藍糖をとかして撒布しこの蔡害を 防いだ。尿素 50 ポソド水 100 ガロン溶液 (1.0モル)

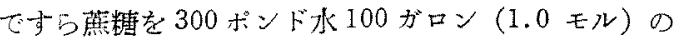
割にまぜるとトマト集は全くやけず，集と果惯の糖分

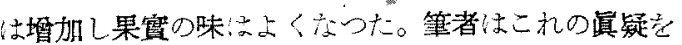

りんご䐑（國光種）て試してみた。りんごは尿素 10 ポンド水100ガロン溶液で䒚踥か゚ツけ 30 ポンド 100

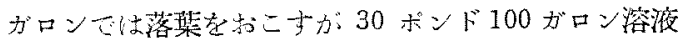
ても同一モルの蔒糖（180 ポンド100がロン）をまぜ 撒布すると藥害は殆どおこらず，實用的には成りた

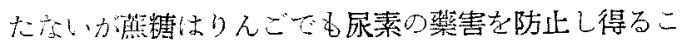

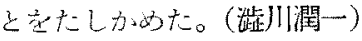

交褙 E.M. EMMERT and J. EDWARD KLINKER (1950. May) : Spraying tomato folage with sucrose to increase carbohydrates and protect against injury by urea sprays. Kentuchy Agr. Exp. Sta. Bull. 550, 1950. 